\title{
Isotretinoin induced dysuria: A case report and review of literature about urological effects of isotretinoin
}

\author{
Izotretinoine bağlı dizüri: Olgu sunumu ve isotretinoinin ürolojik yan etkilerinin \\ değerlendirilmesi
}

๑ Müge Göre Karaali

Erzincan Binali Yıldırım University, Mengücek Gazi Training and Research Hospital, Clinic of Dermatology, Erzincan, Turkey

\begin{abstract}
Isotretinoin is often used in the treatment of severe acne. However, many adverse reactions were reported, including mucocutaneous, metabolic, neurological and psychiatric, ophthalmologic, hematologic side effects and teratogenicity. The mucocutaneous are the most common side effects and often develop in a dose-dependent manner. I present a case of a 20-year-old male with the unusual non-specific dysuria only and review the literature on the urological effects of isotretinoin.

Keywords: Isotretinoin, dysuria, urology
\end{abstract}

Öz

İzotretinoin genellikle şiddetli akne tedavisinde kullanılır. İzotretinoin ile bildirilen mukokutanöz, metabolik, nörolojik ve psikiyatrik, oftalmolojik, hematolojik yan etkiler, teratojenite gibi birçok yan etki vardır. Bunlar arasında mukokutanöz yan etkiler en yaygın olanlardır ve sıklıkla doza bağlı bir şekilde gelişirler. Burada 20 yaşında sistemik izotretinoin kullanan bir erkek hastada görülen dizüri sunulmuş olup, izotretinoinin ürolojik etkileri hakkındaki literatür gözden geçirilmiştir.

Anahtar Kelimeler: İzotretinoin, dizüri, üroloji

\section{Introduction}

Isotretinoin (13 cis-retinoic acid) is a vitamin A-derived agent, which has been used for many years for the treatment of severe nodulocystic or therapy-resistant moderate acne vulgaris. This has been the most effective treatment of choice in all steps of acne pathogenesis. Isotretinoin has anti-inflammatory effects and suppresses sebum secretion, prevents comedo formation, and reduces Propionibacterium acnes colonization". Although the mechanism is not fully understood, it acts through influencing apoptosis, cellular morphogenesis, growth and differentiation ${ }^{2}$.
There are many adverse reactions reported with isotretinoin, including mucocutaneous (cheilitis and dry eyes), metabolic (elevated serum lipids), neurological and psychiatric (depression with suicidal thoughts), ophthalmologic (night blindness), hematologic side effects (neutropenia and thrombocytopenia), and teratogenicity. Thus, the mucocutaneous are the most common side effects and often develop in a dose-dependent manner ${ }^{3,4}$

However, few publications reported adverse effects on the urinary system on systemic isotretinoin treatment, such as acute renal injury, tubulointerstitial nephritis, nephrotic

Address for Correspondence/Yazışma Adresi: Müge Göre Karaali MD, Erzincan Binali Yıldırım University, Mengücek Gazi Training and Research Hospital, Clinic of Dermatology, Erzincan, Turkey Phone: +90 5303093328 E-mail: mugegore@hotmail.com

Received/Geliş Tarihi: 08.04.2021 Accepted/Kabul Tarihi: 26.07.2021

ORCID: orcid.org/0000-0003-0645-0662

Cite this article as: Göre Karaali M. Isotretinoin induced dysuria: A case report and review of literature about urological effects of isotretinoin. TurkdermTurk Arch Dermatol Venereol 2021;55:199-202 
syndrome, urethritis, and hematuria ${ }^{5-17}$. Thus, this may be an overlooked side effect of systemic isotretinoin.

Therefore, I present an unusual side effect of isotretinoin with only non-specific dysuria and review the literature about urological effects of isotretinoin.

\section{Case Report}

A 20-year-old Caucasian male patient was started on $0.5 \mathrm{mg} / \mathrm{kg} /$ day of oral isotretinoin treatment for resistant acne vulgaris therapy. After 2 months he presented to our clinic with a complaint of dysuria.

The patient had no relevant sexual history, and no penile discharge was noted. The urologist examined the meatal mucosa with normal findings. Tests for sexually transmitted and other infectious diseases screening were negative. Urinalysis was performed two times, and both were normal. Urine culture showed no bacterial growth. In addition, urinary ultrasonography and computed tomography were unremarkable. Blood biochemical values were all within the normal range. Furthermore, no side effects of isotretinoin have been observed, except for mild to moderate cheilitis.

The drug was discontinued considering that his complaints were due to the use of isotretinoin. His complaints decreased and disappeared within 2 weeks. After one month, the treatment was administered again with a dose of $0.3 \mathrm{mg} / \mathrm{kg} /$ day, the complaint of dysuria developed within 1 week. Therefore, the treatment was terminated immediately. His symptom disappeared and did not report the return of any urological symptoms. Informed consent was obtained.

\section{Discussion}

Systemic isotretinoin is used in dermatology practice, often in the treatment of acne, and increasingly in many, cases such as seborrheic dermatitis, rosacea, and chemoprevention of cutaneous malignancies ${ }^{18}$. Although isotretinoin has many side effects, mucocutaneous ones are most common, and they are often dose-dependent that can be controlled with a dose modification and symptomatic treatment ${ }^{3,4}$.

However, the pathogenesis of the adverse reactions remains unclear. Keratolytic effects of isotretinoin and apoptosis in sebocytes may lead to alteration of epidermal barrier, dehydration in the degree of stratum corneum, increase of transepidermal water loss and increase skin $\mathrm{pH}$ levels: all these may play a key role in mucocutaneous side effects. In addition, dryness of the mucous membranes, mucosal dermatitis, cheilitis, dry skin, peeling, epistaxis, desquamation, photosensitivity and pruritus are the results of this situation ${ }^{19,20}$.

We have limited information about the effects of systemic isotretinoin on the urinary system. Although there are a limited number of reports, acute renal injury, tubulointerstitial nephritis, nephrotic syndrome, hematuria, and urethritis have been reported in the literature ${ }^{5-17}$. Urological side effects reported in the literature are shown in Table 1.

Dysuria is a symptom of pain, burning, stinging, or itching of the urethra or urethral meatus when urinating. This usually happens due to bladder muscle contraction and peristalsis of the urethra, causing the urine to come in contact with the inflamed mucosal lining leading to stimulation of pain receptors. In addition, this may be caused by urinary tract infections, sexually transmitted diseases (genital herpes,

\begin{tabular}{|c|c|c|c|c|c|c|c|}
\hline Study & Age, sex & Symptoms & $\begin{array}{l}\text { Isotretinoin } \\
\text { dosage per } \\
\text { day }\end{array}$ & $\begin{array}{l}\text { Isotretinoin } \\
\text { duration }\end{array}$ & Findings & Diagnosis & Management \\
\hline Kellock et al. ${ }^{5}$ & $30, M$ & $\begin{array}{l}\text { Dysuria, } \\
\text { hematuria }\end{array}$ & $100 \mathrm{mg} / \mathrm{d}$ & 2 weeks & Dermatitis on meatus & Urethritis & Dosage reduction \\
\hline Kellock et al. ${ }^{5}$ & $25, M$ & $\begin{array}{l}\text { Pain, urethral } \\
\text { discharge }\end{array}$ & $60 \mathrm{mg} / \mathrm{d}$ & 3 months & $\begin{array}{l}\text { Fissure and dermatitis } \\
\text { on meatus }\end{array}$ & Urethritis & $\begin{array}{l}\text { Resolved } \\
\text { spontaneously }\end{array}$ \\
\hline Kellock et al. ${ }^{5}$ & $20, M$ & $\begin{array}{l}\text { Dysuria, } \\
\text { urethral } \\
\text { discharge }\end{array}$ & $60 \mathrm{mg} / \mathrm{d}$ & 6 weeks & Urethral discharge & Urethritis & $\begin{array}{l}\text { Termination of } \\
\text { drug }\end{array}$ \\
\hline $\begin{array}{l}\text { Edwards and } \\
\text { Sonnex }\end{array}$ & $23, \mathrm{M}$ & $\begin{array}{l}\text { Pain, urethral } \\
\text { discharge }\end{array}$ & NM & NM & $\begin{array}{l}\text { Dermatitis on meatus } \\
\text { and urethral discharge }\end{array}$ & Urethritis & Oral tetracycline \\
\hline $\begin{array}{l}\text { Edwards and } \\
\text { Sonnex }\end{array}$ & $35, M$ & $\begin{array}{l}\text { Urethral } \\
\text { discharge }\end{array}$ & NM & 1 week & Urethral discharge & Urethritis & Oral tetracycline \\
\hline Pavese et al. ${ }^{7}$ & $34, \mathrm{M}$ & NM & $40 \mathrm{mg} / \mathrm{d}$ & 2 months & $\begin{array}{l}\text { Creatinine elevation } \\
\text { Urinalysis: } \\
\text { Protein+ } \\
\text { Erythrocytes+ }\end{array}$ & $\begin{array}{l}\text { Acute renal } \\
\text { failure }\end{array}$ & $\begin{array}{l}\text { Termination of } \\
\text { drug }\end{array}$ \\
\hline van Oers et al. ${ }^{8}$ & $19, \mathrm{M}$ & $\begin{array}{l}\text { Facial, } \\
\text { pretbial, ankle } \\
\text { edema }\end{array}$ & $40 \mathrm{mg} / \mathrm{d}$ & 4 months & $\begin{array}{l}\text { Urinalysis: } \\
\text { Protein+ } \\
\text { Proven renal biopsy }\end{array}$ & $\begin{array}{l}\text { Nephrotic } \\
\text { syndrome }+ \\
\text { Minimal change } \\
\text { disease }\end{array}$ & $\begin{array}{l}\text { Termination of } \\
\text { drug and systemic } \\
\text { steroid }\end{array}$ \\
\hline $\begin{array}{l}\text { Sarifakioglu et } \\
\text { al. }{ }^{9}\end{array}$ & $16, M$ & $\begin{array}{l}\text { Dysuria, } \\
\text { hematuria }\end{array}$ & $0.5 \mathrm{mg} / \mathrm{kg} / \mathrm{d}$ & 1 month & $\begin{array}{l}\text { Urinalysis: } \\
\text { Erythrocytes+ }\end{array}$ & $\begin{array}{l}\text { Terminal } \\
\text { hematuria }\end{array}$ & $\begin{array}{l}\text { Termination of } \\
\text { drug }\end{array}$ \\
\hline
\end{tabular}




\begin{tabular}{|c|c|c|c|c|c|c|c|}
\hline Armaly et al. ${ }^{10}$ & $17, \mathrm{~F}$ & $\begin{array}{l}\text { Flank pain, } \\
\text { nausea, and } \\
\text { vomiting }\end{array}$ & NM & 2 months & $\begin{array}{l}\text { Creatinine elevation } \\
\text { Urinanalysis: } \\
\text { Erythrocytes+ } \\
\text { Protein+ }\end{array}$ & $\begin{array}{l}\text { Acute interstitial } \\
\text { nephritis }\end{array}$ & $\begin{array}{l}\text { Termination of } \\
\text { drug }\end{array}$ \\
\hline $\begin{array}{l}\text { Alli and } \\
\text { Yorulmaz }^{11}\end{array}$ & $23, \mathrm{M}$ & $\begin{array}{l}\text { Dysuria, } \\
\text { pruritus }\end{array}$ & $40 \mathrm{mg} / \mathrm{d}$ & 4 months & $\begin{array}{l}\text { Dermatitis on meatus } \\
\text { Urinalysis: } \\
\text { Erythrocytes+ } \\
\text { Epithelial cells++ }\end{array}$ & $\begin{array}{l}\text { Retinoid } \\
\text { dermatitis on } \\
\text { urethral meatus }\end{array}$ & $\begin{array}{l}\text { Dosage reduction } \\
+ \text { symptomatic } \\
\text { treatment } \\
\text { (petrolatum) }\end{array}$ \\
\hline $\begin{array}{l}\text { Kaya Aksoy et } \\
\text { al. }{ }^{12}\end{array}$ & $16, M$ & Palpitation & $40 \mathrm{mg} / \mathrm{d}$ & 3 months & $\begin{array}{l}\text { Creatinine elevation } \\
\text { Urinalysis: glucose+++ } \\
\text { Protein+ } \\
\text { Leukocytes+ } \\
\text { Proven renal biopsy }\end{array}$ & $\begin{array}{l}\text { Eosinophilic } \\
\text { tubulointerstitial } \\
\text { nephritis }\end{array}$ & $\begin{array}{l}\text { Termination of } \\
\text { drug + systemic } \\
\text { steroid }\end{array}$ \\
\hline Yesilkaya et al. ${ }^{13}$ & $\begin{array}{l}15 \text { patients } \\
\text { (16-32 years) }\end{array}$ & Hematuria & $0.5-1 \mathrm{mg} / \mathrm{kg}$ & Scalp & $\begin{array}{l}\text { Urinalysis: } \\
\text { Erythrocytes+ }\end{array}$ & Hematuria & NM \\
\hline $\begin{array}{l}\text { Ballout and } \\
\text { Maatouk }^{14}\end{array}$ & $28, M$ & $\begin{array}{l}\text { Pain, dysuria, } \\
\text { urethral } \\
\text { discharge }\end{array}$ & $60 \mathrm{mg} / \mathrm{d}$ & 1 month & Dermatitis on meatus & Urethritis & Dosage reduction \\
\hline Sivaraj et al. ${ }^{15}$ & $18, M$ & No symptom & $1 \mathrm{mg} / \mathrm{kg} / \mathrm{d}$ & 5 months & $\begin{array}{l}\text { Dermatitis on meatus } \\
\text { and external urethra }\end{array}$ & Urethritis & $\begin{array}{l}\text { Symptomatic } \\
\text { treatment, } \\
\text { resolved after } \\
\text { termination }\end{array}$ \\
\hline $\begin{array}{l}\text { Paredes-Bhushan } \\
\text { et al. }{ }^{16}\end{array}$ & $17, \mathrm{M}$ & $\begin{array}{l}\text { Urine stream } \\
\text { issues }\end{array}$ & $60 \mathrm{mg} / \mathrm{d}$ & 5 weeks & Dermatitis on meatus & Urethritis & $\begin{array}{l}\text { Symptomatic } \\
\text { treatment (topical } \\
\text { steroid) }\end{array}$ \\
\hline Presented case & $20, M$ & Dysuria & $40 \mathrm{mg} / \mathrm{d}$ & 2 months & Not remarkable & $\begin{array}{l}\text { Non-specific } \\
\text { dysuria }\end{array}$ & $\begin{array}{l}\text { Termination of } \\
\text { treatment }\end{array}$ \\
\hline
\end{tabular}

chlamydia, and gonorrhea), stones in the urinary tract, irritation of the urethra due to sexual activity, side effects from some medications, and tumors in the urinary tract. All these problems can cause inflammation or irritation of the urinary tract or genital area, leading to dysuria ${ }^{21}$.

In our presented case, urinary tract infections were ruled out with urinalysis and urinary culture. Although the patient had no sexual history, sexually transmitted diseases were ruled out with serological tests and microbiological investigations. Urinary ultrasonography, and computed tomography for stones and any tumors in the urinary tract were performed and they were also unremarkable. After all these factors were excluded, it was thought that systemic isotretinoin might have mucosal side effects in this patient. Cessation of treatment led to a gradual decrease in symptoms, and the re-administration of the medication resumed the complaints.

Complaints of dysuria have been rarely reported in the literature; however, these patients showed signs of mucosal irritation (erythema of meatus) or hematuria. Sarifakioglu et al. ${ }^{9}$ reported a 16 -year-old boy with dysuria and terminal hematuria after one month of treatment with isotretinoin. Alli and Yorulmaz ${ }^{11}$ also reported a 23-year-old male with dysuria and meatitis during isotretinoin treatment, his symptoms resolved after dosage reduction. Although urethritis is often symptomatic, Sivaraj et al. ${ }^{15}$ reported a case of asymptomatic external urethritis presenting as an erythematous lesion at the tip of the urethra. Unlike these reported cases, there was no extra complaint in our case and skin and mucous membranes was unremarkable. All these side effects can be thought to be due to the xerotic mucosal effect of isotretionin within the urethral mucosa.

The side effects on the urological system of systemic isotretinoin have been reported with an increasing number, and this may be an overlooked side effect of systemic isotretinoin. It may be managed accordingly by dose reduction or termination of the treatment. Being aware of this adverse effect and questioning these side effects will increase our knowledge on this issue.

\section{Ethics}

Informed Consent: It was obtained.

Peer-review: Externally and internally peer-reviewed.

Financial Disclosure: The author declared that this study received no financial support.

\section{References}

1. Landis MN: Optimizing isotretinoin treatment of acne: Update on current recommendations for monitoring, dosing, safety, adverse effects, compliance, and outcomes. Am J Clin Dermatol 2020;21:411-9.

2. Rigopoulos $D$, Larios $G$, Katsambas $A D$ : The role of isotretinoin in acne therapy: why not as first-line therapy? facts and controversies. Clin Dermatol 2010;28:24-30.

3. McLane J: Analysis of common side efects of isotretinoin. J Am Acad Dermatol 2001;45:S188-94

4. Karadağ AS, Çalka Ö, Akdeniz N: Evaluation of side effects of isotretinoin 
in 150 patients with acne vulgaris. Turkderm-Turk Arch Dermatol Venereol 2011;45:37-42.

5. Kellock D, Parslew R, Mendelsohn SS, O'Mahony CP: Non-specific urethritispossible association with isotretinoin therapy. Int J STD AIDS 1996;7:135-6.

6. Edwards S, Sonnex C: Urethritis associated with isotretinoin therapy. Acta Derm Venereol 1997;77:330.

7. Pavese $P$, Kuentz F, Belleville $C$, Rougé $P E$, Elsener $M$ : Renal impairment induced by isotretinoin. Nephrol Dial Transplant 1997;12:1299.

8. van Oers JA, de Leeuw J, van Bommel EF: Nephrotic syndrome associated with isotretinoin. Nephrol Dial Transplant 2000;15:923-4.

9. Sarifakioglu E, Yilmaz AE, Erpolat S: Terminal hematuria associated with oral isotretinoin treatment in a patient with acne vulgaris. Pediatr Dermato 2012;29:668-9.

10. Armaly $Z$, Haj $S$, Bowirrat $A$, et al.: Acute kidney injury following isotretinoin treatment. Am J Case Rep 2013;14:554-6.

11. Alli $N$, Yorulmaz A: An unusual side effect of isotretinoin: retinoid dermatitis affecting external urethral meatus. Cutan Ocul Toxicol 2015;34:176-7.

12. Kaya Aksoy G, Koyun M, Akkaya B, Comak E, Gemici A, Akman S Eosinophilic tubulointerstitial nephritis on treatment with isotretinoin. Eur $J$ Prdiatr 2016;175:2005-6.

13. Yesilkaya B, Alli N, Artuz RF, Ulu E, Kartal D, Cinar SL: The frequency of hematuria in acne vulgaris patients during isotretinoin treatment. Cutan Ocul Toxicol 2017;36:74-6.
14. Ballout RA, Maatouk I: Isotretinoin-induced urethritis versus non-gonococcal urethritis in a man who has sex with men: an open debate. Int J STD AIDS 2018;29:1024-6.

15. Sivaraj K, Friedman J, Morrell D: Onychocryptosis and asymptomatic external urethritis as complications of oral isotretinoin therapy. BMJ Case Rep 2019; 12:e231387.

16. Paredes-Bhushan V, Rezaee ME, Chavez DR: Isotretinoin induced urethritis: A case report \& review of the literature. Urol Case Rep 2019;29:101109.

17. Forouzani-Haghighi B, Karimzadeh I: Isotretinoin and the kidney: Opportunities and threats. Clin Cosmet Investig Dermatol 2020;13:485-94.

18. On SC, Zeichner J: Isotretinoin updates. Dermatol Ther 2013;26:377-89.

19. Del Rosso JQ: Clinical relevance of skin barrier changes associated with the use of oral isotretinoin: the importance of barrier repair therapy in patient management. J Drugs Dermatol 2013;12:626-31.

20. Kmieć ML, Pajor A, Broniarczyk-Dyła G: Evaluation of biophysical skin parameters and assessment of hair growth inpatients with acne treated with isotretinoin. Postepy Dermatol Alergol 2013;30:343-9.

21. Mehta P, Leslie SW, Reddivari AKR: Dysuria. 2021 Aug 12. In: StatPearls [Internet]. Treasure island (FL): StatPearls Publishing; 2021. 